\title{
Interference of some aqueous two-phase system phase-forming components in protein determination by the Bradford method
}

\author{
Sara C. Silvério ${ }^{\mathrm{a} b}$, Sérgio Moreira ${ }^{\mathrm{c}}$, Adriane M.F. Milagres ${ }^{\mathrm{c}}$, Eugénia A. Macedo ${ }^{\mathrm{b}}$, José A. Teixeira ${ }^{\mathrm{a}}$, \\ Solange I. Mussatto ${ }^{\mathrm{a}, *}$ \\ a Institute for Biotechnology and Bioengineering (IBB), Centre of Biological Engineering, University of Minho, 4710-057 Braga, Portugal \\ ${ }^{\mathrm{b}}$ Laboratory of Separation and Reaction Engineering (LSRE), Associate Laboratory LSRE/LCM, Faculdade de Engenharia, Universidade do Porto, $4200-465$ Porto, Portugal \\ ${ }^{\mathrm{c}}$ Department of Biotechnology, Engineering College of Lorena, University of São Paulo, 12602-810 Lorena SP, Brazil
}

\section{A R T I C L E I N F O}

\section{Article history:}

Received 16 October 2011

Received in revised form 24 November 2011

Accepted 6 December 2011

Available online 16 December 2011

\section{Keywords:}

Aqueous two-phase system

Bradford

Interference

Salts

Polymers

\begin{abstract}
A B S T R A C T
The interference of some specific aqueous two-phase system (ATPS) phase-forming components in bovine serum albumin (BSA) determination by the Bradford method was investigated. For this purpose, calibration curves were obtained for $\mathrm{BSA}$ in the presence of different concentrations of salts and polymers. A total of 19 salts $\left[\mathrm{Na}_{2} \mathrm{SO}_{4},\left(\mathrm{NH}_{4}\right)_{2} \mathrm{SO}_{4}, \mathrm{MgSO}_{4}, \mathrm{LiSO}_{4}, \mathrm{Na}_{2} \mathrm{HPO}_{4}\right.$, sodium phosphate buffer ( $\mathrm{pH}$ 7.0), $\mathrm{NaH}_{2} \mathrm{PO}_{4}, \mathrm{~K}_{2} \mathrm{HPO}_{4}$, potassium phosphate buffer ( $\mathrm{pH} 7.0$ ), $\mathrm{KH}_{2} \mathrm{PO}_{4}, \mathrm{C}_{6} \mathrm{H}_{8} \mathrm{O}_{7}, \mathrm{Na}_{3} \mathrm{C}_{6} \mathrm{H}_{5} \mathrm{O}_{7}, \mathrm{KCHO}_{2}$, $\mathrm{NaCHO}_{2}, \mathrm{NaCO}_{3}, \mathrm{NaHCO}_{3}, \mathrm{C}_{2} \mathrm{H}_{4} \mathrm{O}_{2}$, sodium acetate buffer ( $\mathrm{pH} 4.5$ ), and $\mathrm{NaC}_{2} \mathrm{H}_{3} \mathrm{O}_{2}$ ] and 7 polymers [PEG 4000, PEG 8000, PEG 20000, UCON 3900, Ficoll 70000, PES 100000, and PVP 40000] were tested, and each calibration curve was compared with the one obtained for BSA in water. Some concentrations of salts and polymers had considerable effect in the BSA calibration curve. Carbonate salts were responsible for the highest salt interference, whereas citric and acetic acids did not produce interference even in the maximum concentration level tested ( $5 \mathrm{wt} \%$ ). Among the polymers, UCON gave the highest interference, whereas Ficoll did not produce interference when used in concentrations up to $10 \mathrm{wt} \%$. It was concluded that a convenient dilution of the samples prior to the protein quantification is needed to ensure no significant interference from ATPS phase-forming constituents.
\end{abstract}

(c) 2011 Elsevier Inc. All rights reserved.
Aqueous two-phase systems (ATPSs) ${ }^{1}$ are generally obtained by mixing two aqueous solutions of different constituents that become immiscible under certain critical conditions such as temperature and concentration. Both phases are composed mainly of water, and each one is enriched in a different component [1]. ATPSs formed by two polymers or by a polymer and a salt represent traditional systems. Nevertheless, other alternative biphasic systems can be obtained by using surfactants, micellar compounds, or ionic liquids. Due to the high percentage of water present in their composition, ATPSs can provide a gentle environment for the extraction and recovery of sensitive

\footnotetext{
* Corresponding author. Fax: +351253604 429.

E-mail addresses: solange@deb.uminho.pt, solangemussatto@hotmail.com (S.I. Mussatto).

${ }^{1}$ Abbreviations used: ATPS, aqueous two-phase system; $\left(\mathrm{NH}_{4}\right)_{2} \mathrm{SO}_{4}$, ammonium sulfate; $\mathrm{Na}_{2} \mathrm{SO}_{4}$, sodium sulfate; $\mathrm{NaH}_{2} \mathrm{PO}_{4} \cdot 2 \mathrm{H}_{2} \mathrm{O}$, sodium dihydrogen phosphate; $\mathrm{Na}_{2} \mathrm{HPO}_{4}$, disodium hydrogen phosphate; $\mathrm{C}_{6} \mathrm{H}_{8} \mathrm{O}_{7}$, citric acid; $\mathrm{NaHCO}_{3}$, sodium hydrogen carbonate; $\mathrm{C}_{2} \mathrm{H}_{4} \mathrm{O}_{2}$, acetic acid glacial; $\mathrm{NaC}_{2} \mathrm{H}_{3} \mathrm{O}_{2} \cdot 3 \mathrm{H}_{2} \mathrm{O}$, sodium acetate; $\mathrm{Mg}_{2} \mathrm{SO}_{4}$, magnesium sulfate; $\mathrm{Na}_{3} \mathrm{C}_{6} \mathrm{H}_{5} \mathrm{O}_{7} \cdot 2 \mathrm{H}_{2} \mathrm{O}$, trisodium citrate; $\mathrm{KCHO}_{2}$, potassium formate; $\mathrm{NaCHO}_{2}$, sodium formate; $\mathrm{Li}_{2} \mathrm{SO}_{4}$, lithium sulfate; $\mathrm{K}_{2} \mathrm{HPO}_{4}$, dipotassium hydrogen phosphate; $\mathrm{KH}_{2} \mathrm{PO}_{4}$, potassium dihydrogen phosphate; $\mathrm{Na}_{2} \mathrm{CO}_{3}$, sodium carbonate; PEG, polyethylene glycol; Mw, molecular weight; UCON, Ucon 50-HB -5100; PES, hydroxypropyl starch; PVP, polyvinylpyrrolidone; KPB, potassium phos phate buffer; NaPB, sodium phosphate buffer; $A_{595}$, absorbance at $595 \mathrm{~nm}$.
}

biological materials such as proteins. Polymer-polymer ATPSs obtained combining UCON (a random copolymer of 50\% ethylene oxide and $50 \%$ propylene oxide), polyethylene glycol (PEG), polysaccharide Ficoll, hydroxypropyl starch (PES), dextran, and polyvinylpyrrolidone (PVP) have been successfully used to study the partition and extraction of several proteins [2-4]. In the same way, ATPSs composed of PEG or UCON combined with different sulfate, phosphate, citrate, and carbonate salts have been reported as suitable for protein partition and extraction [2,5-7].

Different methodologies can be used for the quantification of proteins, including spectroscopic methods (some aromatic amino acids, namely tryptophan, tyrosine, and phenylalanine, absorb light in ultraviolet $\sim 275-280 \mathrm{~nm}$ ), chemical methods (e.g., the Kjeldahl method that is based on the determination of the total nitrogen content), and colorimetric methods (based on the reaction between some functional groups of proteins and chromogenic reagents that produce colored complexes). Among these methodologies, the colorimetric method proposed by Bradford [8] is the most currently used for protein quantification in ATPSs, probably due to its sensitivity, rapidity, and simplicity. This assay involves the binding of the Coomassie Brilliant Blue G-250 dye to proteins. In practice, an acidic solution of Coomassie is added to a protein 
solution, and the absorbance of the resulting mixture is measured at $595 \mathrm{~nm}$ and compared with the absorbance of the free dye solution (without protein) [8].

Previous studies indicated that free dye can exist in four different ionic forms with $\mathrm{p} K_{\mathrm{a}}$ values of $1.15,1.82$, and 12.40 [9]. Under the acidic conditions of the Bradford assay, only three equilibrium forms are present: the cationic red dye form (maximum wavelength $=470 \mathrm{~nm}$ ), the neutral greenish dye form (maximum wavelength $=650 \mathrm{~nm}$ ), and the anionic blue dye form (maximum wavelength $=590 \mathrm{~nm}$ ). These three forms are found in different fractions, and each one provides a different contribution to the total absorbance of the free dye solution at $595 \mathrm{~nm}$. It was demonstrated that, under the assay conditions, the highest fraction belongs to the red form [9]. On the other hand, there is evidence that the ionic blue dye form (the lowest fraction of the three forms) is the one that binds preferably to proteins [10]. During the assay, it is assumed that the equilibrium among the cationic, neutral, and anionic forms is forced to the anionic side as more proteins are bound to the anion $[10,11]$. As a consequence of the binding, a shift in the absorbance peak of the dye solution is observed. The maximum wavelength changes from 470 to $620 \mathrm{~nm}$, the maximum wavelength for the protein-dye complex. However, due to the considerable fraction of green form present at the usual $\mathrm{pH}$ of the assay, the wavelength typically chosen to measure the absorbance of the complex is $595 \mathrm{~nm}[9,11]$. This wavelength represents the best compromise because it maximizes the absorbance due to the protein-dye complex while minimizing the absorbance from the green form [11]. In addition, the protein-dye complex has a higher molar absorptivity at $595 \mathrm{~nm}$ than any of the free dye forms.

Apparently, the dye binding process is essentially governed by electrostatic interactions between the ionized sulfonic groups of the dye and the positively charged functional groups of the protein. Arginine and lysine residues seem to be the places where the dye binds most readily, but binding to some aromatic residues (e.g., tryptophan, phenylalanine) can also be involved, suggesting some hydrophobic interaction between proteins and dye [12]. This behavior may lead to some variations in the quantification of different proteins because the method response depends on the composition of the proteins. Coomassie does not bind to free arginine or lysine, or to peptides smaller than $3000 \mathrm{Da}$, which can minimize some interference in the sample [13].

The binding process is fast ( $<5 \mathrm{~min}$ ), and the protein-dye complex formed is stable for approximately $1 \mathrm{~h}$ [8]. The use of a single reactive and the sensitivity of the dye to small amounts of protein ( $<5 \mu \mathrm{g}$ of protein can easily be detected) make the Bradford method widely used for protein determination [14]. On the other hand, it was shown in several studies that the Bradford assay may suffer significant interference from some compounds that may be found in protein samples. Interferences caused by the presence of detergents [15], drugs [16], sugars [17], pharmaceutical polymers [18], and some reagents and buffers [13] have already been reported in the literature. However, poor information has been reported about the interference of specific compounds used to form ATPSs. Therefore, the current study aimed to identify and minimize the effect of some salts and polymers typically used in ATPSs on the Bradford method.

\section{Materials and methods}

\section{Materials}

Salts

Ammonium sulfate $\left[\left(\mathrm{NH}_{4}\right)_{2} \mathrm{SO}_{4}\right]$ ( $\mathrm{GR}$ for analysis), sodium sulfate $\left(\mathrm{Na}_{2} \mathrm{SO}_{4}\right)$ (GR for analysis), sodium dihydrogen phosphate $\left(\mathrm{NaH}_{2-}\right.$ $\left.\mathrm{PO}_{4} \cdot 2 \mathrm{H}_{2} \mathrm{O}\right)$ (p.a., Reag. Ph Eur), disodium hydrogen phosphate
$\left(\mathrm{Na}_{2} \mathrm{HPO}_{4}\right)$ (anhydrous, GR for analysis, ACS, Reag. Ph Eur), citric acid $\left(\mathrm{C}_{6} \mathrm{H}_{8} \mathrm{O}_{7}\right)$ (anhydrous, for synthesis), sodium hydrogen carbonate $\left(\mathrm{NaHCO}_{3}\right)$ (GR for analysis), acetic acid glacial $\left(\mathrm{C}_{2} \mathrm{H}_{4} \mathrm{O}_{2}\right)(100 \% \mathrm{GR}$ for analysis), and sodium acetate $\left(\mathrm{NaC}_{2} \mathrm{H}_{3} \mathrm{O}_{2} \cdot 3 \mathrm{H}_{2} \mathrm{O}\right)$ ( $\mathrm{GR}$ for analysis, ACS, ISO, Reag. Ph Eur) were supplied by Merck (Germany). Magnesium sulfate $\left(\mathrm{Mg}_{2} \mathrm{SO}_{4}\right)$ (minimum 99.5\%) and trisodium citrate $\left(\mathrm{Na}_{3}\right.$ $\mathrm{C}_{6} \mathrm{H}_{5} \mathrm{O}_{7} \cdot 2 \mathrm{H}_{2} \mathrm{O}$ ) (ACS reagent, $\geqslant 99.0 \%$ ), potassium formate $\left(\mathrm{KCHO}_{2}\right)$ (purum p.a.), and sodium formate $\left(\mathrm{NaCHO}_{2}\right)$ (puriss. p.a., ACS $\geqslant 99.0 \%$ ) were purchased from Sigma-Aldrich in Japan, Germany, and the United States, respectively. Lithium sulfate $\left(\mathrm{Li}_{2} \mathrm{SO}_{4}\right)$ (purum p.a., $\geqslant 98 \%$ ) was obtained from Fluka (USA). Dipotassium hydrogen phosphate $\left(\mathrm{K}_{2} \mathrm{HPO}_{4}\right)$ (anhydrous, $\mathrm{PA}$ ) was obtained from Panreac (Spain). Potassium dihydrogen phosphate $\left(\mathrm{KH}_{2} \mathrm{PO}_{4}\right)$ (anhydrous, $\geqslant 99.9 \%$ ) was provided by USB (USA). Sodium carbonate $\left(\mathrm{Na}_{2} \mathrm{CO}_{3}\right)$ (anhydrous, 99.6\% for analysis ACS) was supplied by Acros Organics (Belgium).

\section{Polymers}

Polyethylene glycols (PEGs) [average molecular weight (Mw) 4000 (PEG 4000) and 20000 (PEG 20000)] were obtained from Merck. PEG 8000 was obtained from Sigma-Aldrich (USA). Ucon 50-HB-5100 (UCON) [average Mw 3900 (UCON 3900)], a random copolymer of $50 \%$ ethylene oxide and $50 \%$ propylene oxide, was purchased from Union Carbide (USA). Polysaccharide Ficoll PM70 [average Mw 70000 (Ficoll 70000)] was provided by GE Healthcare Biosciences (Sweden). Hydroxypropyl starch (Reppal PES-100) [average Mw 100000 (PES 100000)] was purchased from Reppe (Sweden). Polyvinylpyrrolidone (PVP-40) [average Mw 40000 (PVP 40000)] was obtained from Sigma-Aldrich (USA).

Stock solutions of each component were prepared in Milli-Q water $\left[\sim 20 \mathrm{wt} \%\right.$ for $\left(\mathrm{NH}_{4}\right)_{2} \mathrm{SO}_{4}, 17 \mathrm{wt} \%$ for $\mathrm{Na}_{2} \mathrm{SO}_{4}, 26 \mathrm{wt} \%$ for $\mathrm{MgSO}_{4}, 23 \mathrm{wt} \%$ for $\mathrm{Li}_{2} \mathrm{SO}_{4}, 15 \mathrm{wt} \%$ for $\mathrm{KH}_{2} \mathrm{PO}_{4}, 20 \mathrm{wt} \%$ for $\mathrm{NaH}_{2} \mathrm{PO}_{4}$, 17 wt\% for $\mathrm{K}_{2} \mathrm{HPO}_{4}, 7$ wt\% for $\mathrm{Na}_{2} \mathrm{HPO}_{4}, 20$ wt\% for $\mathrm{C}_{6} \mathrm{H}_{8} \mathrm{O}_{7}, 21 \mathrm{wt} \%$ for $\mathrm{Na}_{3} \mathrm{C}_{6} \mathrm{H}_{5} \mathrm{O}_{7}, 20 \mathrm{wt} \%$ for $\mathrm{KCHO}_{2}, 20 \mathrm{wt} \%$ for $\mathrm{NaCHO}_{2}, 20 \mathrm{wt} \%$ for $\mathrm{NaCO}_{3}, 7 \mathrm{wt} \%$ for $\mathrm{NaHCO}_{3}, 50 \mathrm{wt} \%$ for $\mathrm{C}_{2} \mathrm{H}_{4} \mathrm{O}_{2}, 20 \mathrm{wt} \%$ for $\mathrm{Na}-$ $\mathrm{C}_{2} \mathrm{H}_{3} \mathrm{O}_{2}, 50 \mathrm{wt} \%$ for PEG 4000, 50 wt\% for PEG 8000, $49 \mathrm{wt} \%$ for PEG 20000, 50 wt\% for UCON, 44 wt\% for Ficoll, 33 wt\% for PES, and $45 \mathrm{wt} \%$ for PVP].

All concentrations were obtained gravimetrically after evaporation on a heating plate (Stuart Hotplate SB300) for the salts or after lyophilization (ScanVac, model CoolSafe 55-4) for the polymers. Potassium phosphate buffer (KPB) (1 M, pH 7.0) was obtained by combining $\mathrm{KH}_{2} \mathrm{PO}_{4}$ and $\mathrm{K}_{2} \mathrm{HPO}_{4}$ salts. Sodium phosphate buffer

Table 1

Salt concentrations determined as suitable to be used in the Bradford method.

\begin{tabular}{ll}
\hline Salt & Concentration (wt\%) \\
\hline $\mathrm{Na}_{2} \mathrm{CO}_{3}$ & 0.5 \\
$\mathrm{NaHCO}_{3}$ & 0.5 \\
$\mathrm{NaCHO}_{2}$ & 0.5 \\
$\mathrm{KCHO}_{2}$ & 0.5 \\
$\mathrm{Na}_{2} \mathrm{SO}_{4}$ & 1 \\
$\left(\mathrm{NH}_{4}\right)_{2} \mathrm{SO}_{4}$ & 0.5 \\
$\mathrm{Li}_{2} \mathrm{SO}_{4}$ & 1 \\
$\mathrm{MgSO}_{4}$ & 1 \\
$\mathrm{NaH}_{2} \mathrm{PO}_{4}$ & 1 \\
$\mathrm{Na}_{2} \mathrm{HPO}_{4}$ & 0.5 \\
$\mathrm{NaPB}_{2} \mathrm{pH} \mathrm{7.0)}$ & 0.5 \\
$\mathrm{KH}_{2} \mathrm{PO}_{4}$ & 1 \\
$\mathrm{~K}_{2} \mathrm{HPO}_{4}$ & 0.5 \\
$\mathrm{KPB}_{2}\left(\mathrm{pH}_{7.0}\right)$ & 0.5 \\
$\mathrm{C}_{6} \mathrm{H}_{8} \mathrm{O}_{7}$ & 5 \\
$\mathrm{Na}_{3} \mathrm{C}_{6} \mathrm{H}_{5} \mathrm{O}_{7}$ & 0.5 \\
$\mathrm{Citrate} \mathrm{buffer} \mathrm{(pH} \mathrm{4.5)}_{\mathrm{C}_{2} \mathrm{H}_{4} \mathrm{O}_{2}}$ & 1 \\
$\mathrm{NaC}_{2} \mathrm{H}_{3} \mathrm{O}_{2}$ & 5 \\
\hline
\end{tabular}


(NaPB) (1 M, pH 7.0) was prepared by mixing $\mathrm{NaH}_{2} \mathrm{PO}_{4}$ and $\mathrm{Na}_{2} \mathrm{H}-$ $\mathrm{PO}_{4}$ salts. Citrate buffer (1 M, pH 4.5 ) was obtained by combining $\mathrm{C}_{6} \mathrm{H}_{8} \mathrm{O}_{7}$ and $\mathrm{Na}_{3} \mathrm{C}_{6} \mathrm{H}_{5} \mathrm{O}_{7}$ salts. Buffer concentrations ( $\sim 14$ wt\% for potassium phosphate buffer, $13 \mathrm{wt} \%$ for sodium phosphate buffer, and $21 \mathrm{wt} \%$ for citrate buffer) were obtained gravimetrically after evaporation on a heating plate. The $\mathrm{pH}$ values were confirmed using a pH meter (VWR, model SimpHony SB70P). All of the weightings were carried out on an Adam Equipment balance (model AAA250L) that was precise to within $\pm 0.2 \mathrm{mg}$.

Coomassie Protein Assay Reagent and BSA Standard Ampoules ( $2 \mathrm{mg} / \mathrm{ml}$ in a solution of $0.9 \%$ saline and $0.05 \%$ sodium azide) were

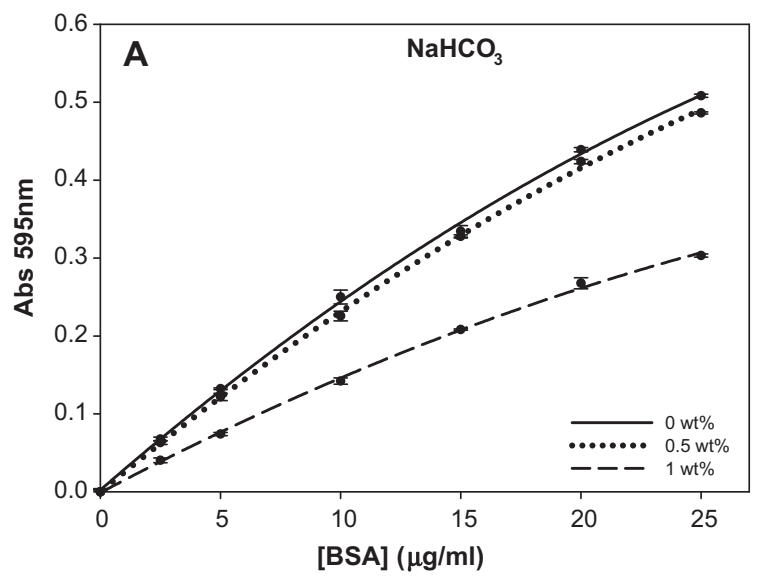

purchased from Pierce Biotechnology (USA). Milli-Q water was used for all of the diluting purposes.

\section{Methods}

Standard solutions used in all of the calibration curves were obtained after correct dilution of BSA standard ampoules $(2 \mathrm{mg} / \mathrm{ml})$. For the BSA standard calibration curve (absent in salts and polymers), as well as for the calibration curves of BSA in the presence of different concentrations of salts (0.5-5 wt\%) and polymers (1$10 \mathrm{wt} \%)$, the dilutions were prepared in Milli-Q water.

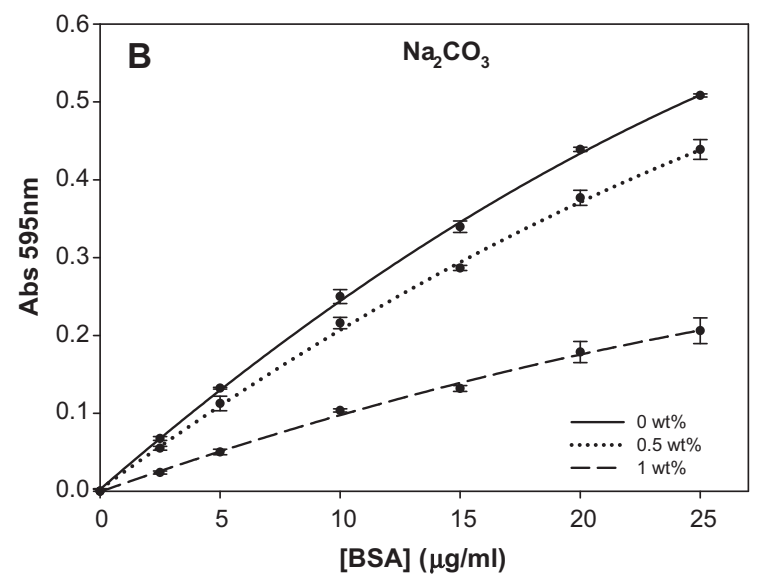

Fig.1. BSA calibration curves in the presence of different concentrations of $\mathrm{NaHCO}_{3}(\mathrm{~A})$ and $\mathrm{Na}_{2} \mathrm{CO}_{3}(\mathrm{~B})$.
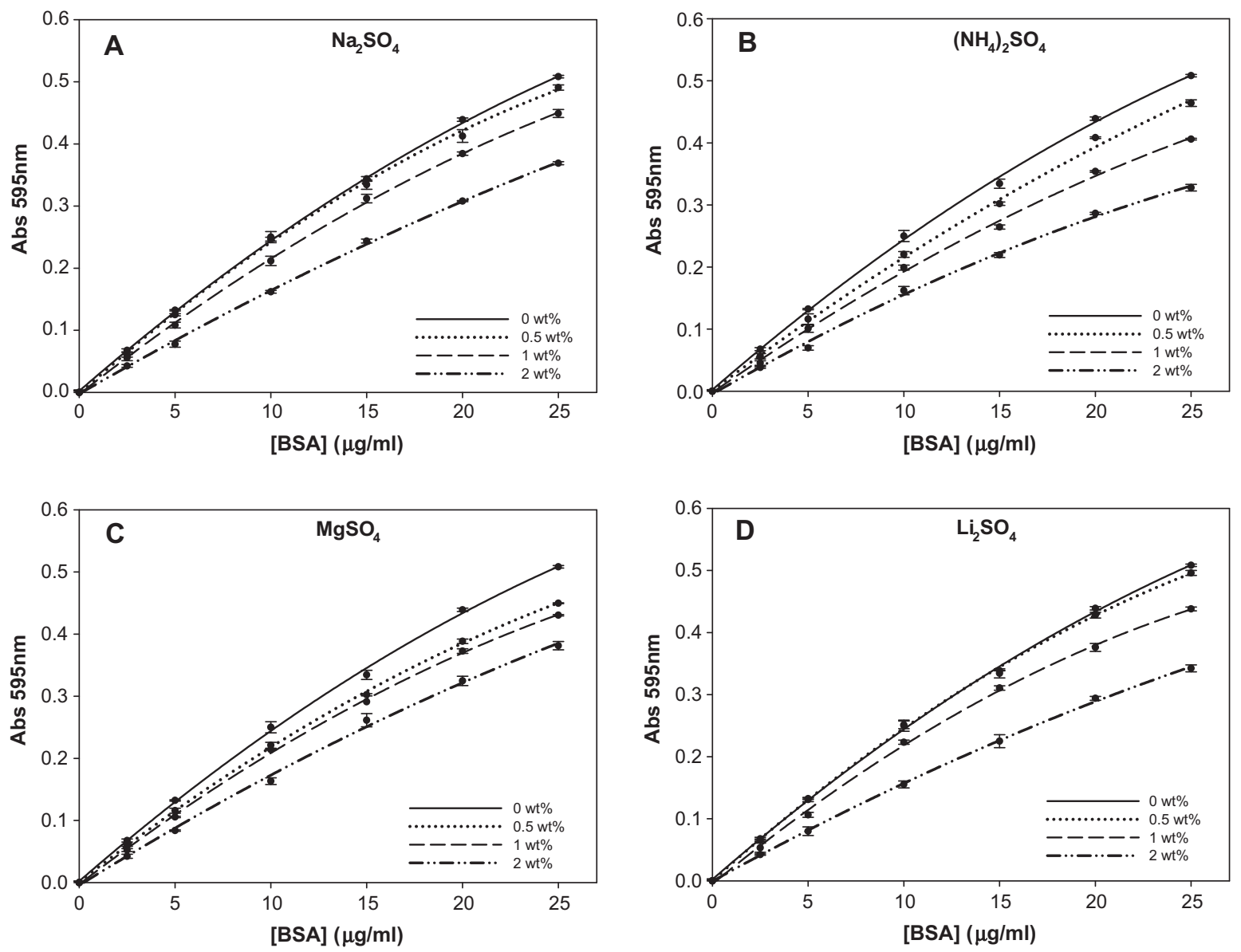

Fig.2. BSA calibration curves in the presence of different concentrations of $\mathrm{Na}_{2} \mathrm{SO}_{4}(\mathrm{~A}),\left(\mathrm{NH}_{4}\right)_{2} \mathrm{SO}_{4}(\mathrm{~B}), \mathrm{MgSO}_{4}(\mathrm{C}), \mathrm{and} \mathrm{Li}_{2} \mathrm{SO}_{4}(\mathrm{D})$. 
Protein determination was carried out by using the Micro Microplate Protocol (working range: $1-25 \mu \mathrm{g} / \mathrm{ml}$ ) described in the Pierce Biotechnology instructions and involved adding $150 \mu \mathrm{l}$ of each standard BSA solution and $150 \mu \mathrm{l}$ of the Coomassie reagent in the microplate well, with subsequent mixing of the solutions in a plate shaker for $30 \mathrm{~s}$, followed by incubation at room temperature for $10 \mathrm{~min}$ and measurement of the absorbance at $595 \mathrm{~nm}$ $\left(A_{595}\right)$. Each experiment was performed in triplicate, and each standard solution was also measured in triplicate. The average $A_{595}$ value (after correction of the corresponding blank) was then calculated.

To estimate the interference caused by the ATPS constituents, the average percentage of variation occurring in $A_{595}$ compared with the BSA standard calibration curve was calculated. According to other authors [19], an $A_{595}$ reduction greater than $15 \%$ was considered as significant interference in the assay. For all of the average percentages of variation, standard deviations below $5 \%$ were obtained.

\section{Results and discussion}

Several concentrations of salts and polymers had considerable effects in the BSA calibration curve obtained by the Bradford microassay method. In fact, only a few salts and polymers could be considered as noninterfering, as discussed in the following sections.

\section{Salts}

A large number of the salts presented considerable interference in the Bradford method when in concentrations above $0.5 \mathrm{wt} \%$, and nearly all of them showed interference when in concentrations above $1 \mathrm{wt} \%$ (Table 1 ). A concentration value of $2 \mathrm{wt} \%$ was the maximum possible to be tested for nearly all of the salts due to the high interferences observed with the exception of the most acidic salts $\left(\mathrm{C}_{2} \mathrm{H}_{4} \mathrm{O}_{2}\right.$ and $\left.\mathrm{C}_{6} \mathrm{H}_{8} \mathrm{O}_{7}\right)$, which could be evaluated in a concentration up to $5 \mathrm{wt} \%$. The differences observed can be related to the nature of the salts, namely to their acidic or basic behavior. As the Bradford assay taking place in acid conditions, the addition of a salt with the ability to modify the $\mathrm{pH}$ of the dye solution may compromise the method response. A variation on the $\mathrm{pH}$ of the assay will change the composition of the dye solution given that different ionic forms can be present, and this will affect the dyeprotein binding and the $A_{595}$ values as a consequence. Therefore, the presence of basic salts has a larger influence on the BSA calibration curve than does the presence of acidic salts. Such a fact was observed in the current study, where smaller interferences were found for the most acidic salts (Table 1 ).

The carbonate salts $\mathrm{NaHCO}_{3}$ and $\mathrm{Na}_{2} \mathrm{CO}_{3}$ caused $A_{595}$ reductions greater than $15 \%$ when present in a concentration of $1 \mathrm{wt} \%$ (Fig. 1); however, $A_{595}$ reductions caused by $\mathrm{Na}_{2} \mathrm{CO}_{3}$ were more significant than the reductions caused by $\mathrm{NaHCO}_{3}$. The typical reaction between carbonate and acid was followed by the production of effervescence. For concentrations above $1 \mathrm{wt} \%$, no results were obtained due to the strong effervescence produced.

Very similar interference was caused by the formate salts $\mathrm{NaCHO}_{2}$ and $\mathrm{KCHO}_{2}$ (see Fig. $1 \mathrm{~S}$ in supplementary material), suggesting that the results were not dependent on the cation present in this kind of salts. In both cases, $A_{595}$ reductions greater than $15 \%$ were obtained when more than $1 \mathrm{wt} \%$ salt was present. On the other hand, slight changes in the calibration curve were observed according to the cation present in the sulfate salts $\left[\mathrm{Na}_{2} \mathrm{SO}_{4}\right.$, $\left(\mathrm{NH}_{4}\right)_{2} \mathrm{SO}_{4}, \mathrm{MgSO}_{4}$, and $\mathrm{Li}_{2} \mathrm{SO}_{4}$ ] (Fig. 2). For example, for $\left(\mathrm{NH}_{4}\right)_{2} \mathrm{SO}_{4}$ the increase in salt concentration produced a gradual reduction in $A_{595}$, whereas for $\mathrm{Na}_{2} \mathrm{SO}_{4}$ and $\mathrm{Li}_{2} \mathrm{SO}_{4}$ a greater reduction in $A_{595}$ was
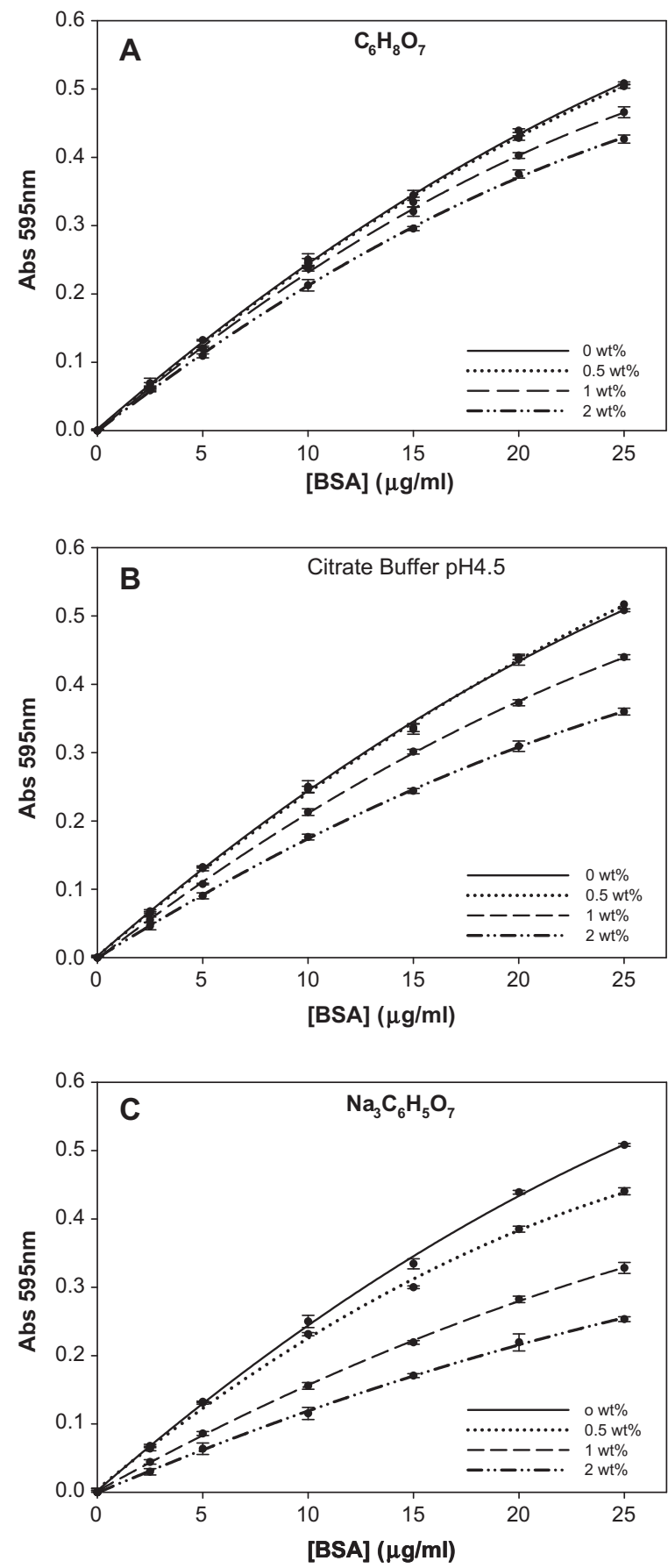

Fig.3. BSA calibration curves in the presence of different concentrations of $\mathrm{C}_{6} \mathrm{H}_{8} \mathrm{O}_{7}$ (A), citrate buffer ( $\mathrm{pH} 4.5$ ) (B), and $\mathrm{Na}_{3} \mathrm{C}_{6} \mathrm{H}_{5} \mathrm{O}_{7}(\mathrm{C})$.

observed when using between 1 and 2 wt\% salt. $\mathrm{MgSO}_{4}$ showed similar $A_{595}$ reductions in the presence of 0.5 or $1 \mathrm{wt} \%$ salt. In brief, all of the sulfate salts showed interference when used in concentrations above $1 \mathrm{wt} \%$ except $\left(\mathrm{NH}_{4}\right)_{2} \mathrm{SO}_{4}$, which showed interference when in concentrations above $0.5 \mathrm{wt} \%$. In addition, the interference produced by the other sulfate salts in a concentration of $1 \mathrm{wt} \%$ was very similar $\left(A_{595}\right.$ reduction of $\left.\sim 15 \%\right)$, whereas for $\left(\mathrm{NH}_{4}\right)_{2} \mathrm{SO}_{4}$ the interference was more pronounced $\left(A_{595}\right.$ reduction of $25 \%$ ).

Similar profiles of interference were observed when comparing sodium and potassium phosphate salts (see Figs. 2S and 3S in supplementary material). In all of the cases, salt concentrations of $0.5 \mathrm{wt} \%$ gave $A_{595}$ reductions less than $10 \%$. However, for concentrations above $0.5 \mathrm{wt} \%$, the interference in the BSA curve 

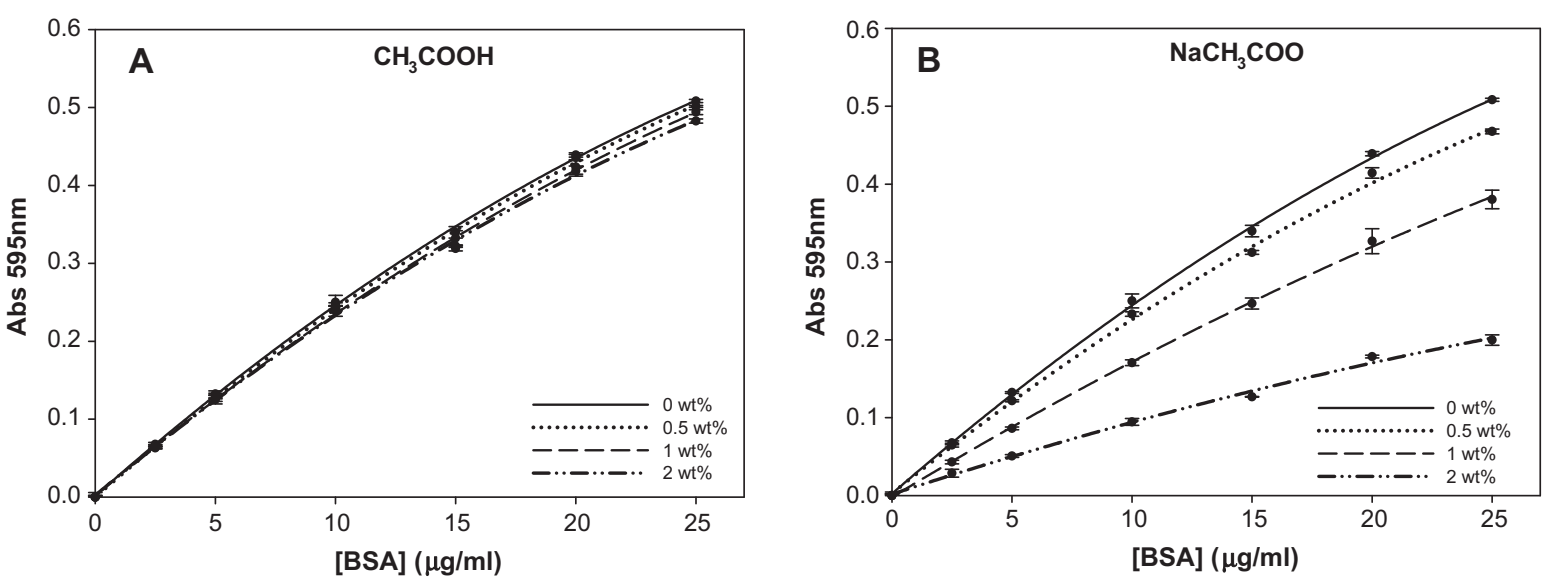

Fig.4. BSA calibration curves in the presence of different concentrations of $\mathrm{CH}_{3} \mathrm{COOH}(\mathrm{A})$ and $\mathrm{NaCH} \mathrm{COO}_{3}(\mathrm{~B})$.

Table 2

Polymer concentrations determined as suitable to be used in the Bradford method.

\begin{tabular}{lc}
\hline Polymer & Concentration (wt\%) \\
\hline PEG 4000 & 5 \\
PEG 8000 & 5 \\
PEG 20000 & 5 \\
Reppal PES & 2 \\
UCON & 2 \\
PVP & 2 \\
Ficoll & 10 \\
\hline
\end{tabular}

increased as follows: hydrogen phosphate > buffer $(\mathrm{pH} 7.0)>$ dihydrogen phosphate. This could be due to some variations in the $\mathrm{pH}$ of the assay caused by the addition of the salts. $\mathrm{Na}_{2} \mathrm{HPO}_{4}, \mathrm{NaPB}$, $\mathrm{K}_{2} \mathrm{HPO}_{4}$, and $\mathrm{KPB}$ showed interference when in concentrations above $0.5 \mathrm{wt} \%$, whereas $\mathrm{NaH}_{2} \mathrm{PO}_{4}$ and $\mathrm{KH}_{2} \mathrm{PO}_{4}$ showed interference only when in concentrations above $1 \mathrm{wt} \%$.

An analogous behavior was observed for citrate salts $\left[\mathrm{C}_{6} \mathrm{H}_{8} \mathrm{O}_{7}\right.$,

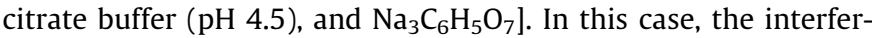
ence in the BSA curve increased as follows: $\mathrm{Na}_{3} \mathrm{C}_{6} \mathrm{H}_{5} \mathrm{O}_{7}>$ citrate buffer ( $\mathrm{pH} 4.5$ ) $>\mathrm{C}_{6} \mathrm{H}_{8} \mathrm{O}_{7}$ (Fig. 3). Once more, variations occurring in the $\mathrm{pH}$ of the assay could be a possible justification for this fact. The results revealed that $\mathrm{Na}_{3} \mathrm{C}_{6} \mathrm{H}_{5} \mathrm{O}_{7}$ caused interference when in concentrations above $0.5 \mathrm{wt} \%$, whereas citrate buffer ( $\mathrm{pH} 4.5$ ) produced interference only when in concentrations above $1 \mathrm{wt} \%$. For $\mathrm{C}_{2} \mathrm{H}_{4} \mathrm{O}_{2}$, no significant interference was observed up to the maximum concentration tested ( $5 \mathrm{wt} \%$ ).

The presence of acetate salts $\left(\mathrm{C}_{2} \mathrm{H}_{4} \mathrm{O}_{2}\right.$ and $\left.\mathrm{NaC}_{2} \mathrm{H}_{3} \mathrm{O}_{2}\right)$ gave the same profile observed for citrates (Fig. 4). Probably due to the changes caused in the $\mathrm{pH}$ of the assay, $\mathrm{NaC}_{2} \mathrm{H}_{3} \mathrm{O}_{2}$ produced much more interference than $\mathrm{C}_{2} \mathrm{H}_{4} \mathrm{O}_{2} . \mathrm{NaC}_{2} \mathrm{H}_{3} \mathrm{O}_{2}$ presented great interference when in concentrations above $0.5 \mathrm{wt} \%$, whereas $\mathrm{C}_{2} \mathrm{H}_{4} \mathrm{O}_{2}$ showed no interference up to the maximum concentration value tested ( 5 wt\%). Furthermore, among all of the salts, $\mathrm{C}_{2} \mathrm{H}_{4} \mathrm{O}_{2}$ was the one that produced the lowest interference $\left(A_{595}\right.$ reduction of $5 \%$ when $5 \mathrm{wt} \%$ salt was present).

\section{Polymers}

The polymers investigated in the current study produced lower interference than most of the evaluated salts (Table 2 ). In addition, the $A_{595}$ reduction observed for the maximum polymer concentration tested ( $10 \mathrm{wt} \%$ ) was comparable to that obtained for the maximum concentration tested for most of the salts (2 wt\%). As a whole, nearly all of the polymers showed interference on the Bradford method, as discussed below.
PEG is one of the most used polymers in ATPSs because it can form biphasic systems with both other polymers and salts. In this work, three different PEG polymers $(4000,8000$, and 20000) were used to evaluate the influence of the molecular weight in the BSA calibration curve. However, no differences were found for the PEG concentrations tested (see Fig. $4 \mathrm{~S}$ in supplementary material). In the three cases, interference was detected only for the maximum polymer concentration tested (10 wt\%), with an $A_{595}$ reduction of approximately $30 \%$. Barbosa and coworkers [19] did not find relevant differences in the calibration curve when $10 \mathrm{wt} \%$ of PEGs with different molecular weights $(600,1000,3350$, and 10000) were present. According to these authors, interference was observed only for polymer concentrations of $20 \mathrm{wt} \%$, and the $A_{595}$ reductions obtained for a concentration of $10 \mathrm{wt} \%$ corresponded to half of the value obtained in the current study. These differences could be related to the preparation of the BSA sample, which was prepared in Millipore water in the current study and in $5 \mathrm{mM}$ Tris- $\mathrm{HCl}$ buffer $(\mathrm{pH} 7.5)$ in the other work.

When comparing the polymers Reppal PES and UCON, it was observed that, in spite of being chemically different compounds (UCON is a random copolymer composed of $50 \%$ ethylene oxide and 50\% propylene oxide, whereas Reppal PES is a hydroxypropyl starch) and having different molecular weights (100000 for Reppal PES and 3900 for UCON), these polymers provided similar interference in the BSA calibration curve (see Fig. 5S in supplementary material). In both cases, interference was detected when the polymer was present in a concentration of $5 \mathrm{wt} \%$. For $2 \mathrm{wt} \%$ polymer, $A_{595}$ reductions between $8 \%$ and $14 \%$ were obtained, which did not significantly influence the protein determination.

The interference caused by PVP is shown in Fig. 5A. For a 2 wt $\%$ concentration of this polymer, $A_{595}$ reductions of $5 \%$ were obtained (no interference). However, for higher concentration values, the $A_{595}$ reductions increased and interference was observed. On the other hand, no interference was observed for Ficoll up to the maximum concentration value tested ( $10 \mathrm{wt} \%$; see Fig. 5B). Similarly, Banik and coworkers [17] reported interference of the Ficoll polymer in the BSA determination by the Bradford assay only when present in ion concentrations above $10 \mathrm{wt} \%$. Interference is connected to the ability of the sugars to compete with proteins for binging and sequestering the Coomassie dye. This phenomenon may cause significant deviations in protein estimation if it is not taken into account during the calculation of the protein concentration. In the current study, Ficoll was tested in concentration values lower than those reported by Banik and coworkers, and the polymer produced $A_{595}$ reductions less than $2 \%$ for all of the concentrations tested. 

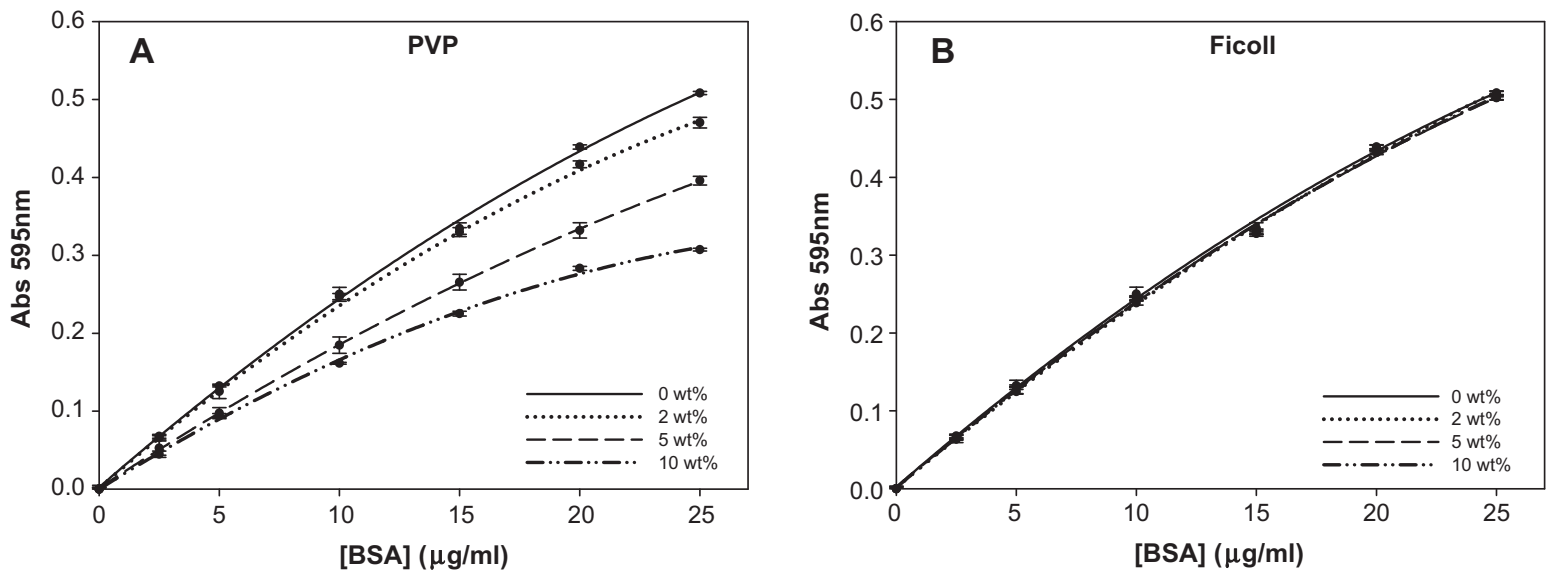

Fig.5. BSA calibration curves in the presence of different concentrations of PVP (A) and Ficoll (B).

\section{Conclusions}

The results achieved in the current study revealed that certain concentrations of salts and polymers are able to produce considerable effects in the BSA calibration curve. We also found a more significant interference of the salts than of the polymers in the curve. Nearly all of the salts caused interference when in concentrations $\geqslant 1 \mathrm{wt} \%$, whereas for the polymers interference was found only in concentrations above $2 \mathrm{wt} \%$. Carbonate salts $\left(\mathrm{Na}_{2} \mathrm{CO}_{3}\right.$ and $\mathrm{NaH}-$ $\mathrm{CO}_{3}$ ) produced the highest interference among the salts, whereas UCON and PES gave the most elevated interference among the polymers. The only ATPS phase-forming constituents that did not produce interference up to the maximum concentration value tested were $\mathrm{C}_{6} \mathrm{H}_{8} \mathrm{O}_{7}, \mathrm{C}_{2} \mathrm{H}_{4} \mathrm{O}_{2}$, and Ficoll. Based on these results, it was concluded that to ensure no significant interference of ATPS phase-forming components in protein determination by the Bradford method, the samples need to be conveniently diluted before protein quantification. Alternatively, a calibration curve in the presence of the phase-forming components could also be prepared prior to protein determination.

\section{Appendix A. Supplementary data}

Supplementary data associated with this article can be found, in the online version, at doi:10.1016/j.ab.2011.12.020.

\section{References}

[1] B.Y. Zaslavsky, Aqueous Two-Phase Partitioning: Physical Chemistry and Bioanalytical Applications, Marcel Dekker, New York, 1994.

[2] M. Pereira, Y. Wu, A. Venâncio, J.A. Teixeira, Aqueous two-phase extraction using thermoseparating polymer: a new system for the separation of endopolygalacturonase, Biochem. Eng. J. 15 (2003) 131-138.
[3] P.P. Madeira, J.A. Teixeira, E.A. Macedo, L.M. Mikheeva, B.Y. Zaslavsky, “On the Collander equation": protein partitioning in polymer/polymer aqueous twophase systems, J. Chromatogr. A 1190 (2008) 39-43.

[4] S. Fernandes, H. Kim, R. Hatti-Kaul, Affinity extraction of dye- and metal ionbinding proteins in polyvinylpyrrolidone-based aqueous two-phase system, Protein Expr. Purif. 24 (2002) 460-469.

[5] R. Dembczynski, W. Bialas, T. Jankowski, Recycling of phase components during lysozyme extraction from hen egg white in the EO50PO50/ $\mathrm{K}_{2} \mathrm{HPO}_{4}$ aqueous two-phase system, Biochem. Eng. J. 51 (2010) 24-31.

[6] B.K. Sarangi, D.P. Pattanaik, K. Rathinaraj, N.M. Sachindra, M.C. Madhusudan, N.S. Mahendrakar, Purification of alkaline protease from chicken intestine by aqueous two phase system of polyethylene glycol and sodium citrate, J. Food Sci. Technol. 48 (2011) 36-44.

[7] F.C. Oliveira, J.S.R. Coimbra, L.H.M. Silva, E.E.G. Rojas, M.C.H. Silva, Ovomucoid partitioning in aqueous two-phase systems, Biochem. Eng. J. 47 (2009) 55-60.

[8] M.M. Bradford, A rapid and sensitive method for the quantitation of microgram quantities of protein utilizing the principle of protein-dye binding, Anal. Biochem. 72 (1976) 248-254.

[9] H.J. Chial, H.B. Thomson, A.G. Splittgerber, A spectral study of the charge forms of Coomassie Blue G, Anal. Biochem. 209 (1993) 258-266.

[10] H.J. Chial, A.G. Splittgerber, A comparison of the binding of Coomassie Brilliant Blue to proteins at low and neutral pH, Anal. Biochem. 213 (1993) 362-369.

[11] S.J. Compton, C.G. Jones, Mechanism of dye response and interference in the Bradford protein assay, Anal. Biochem. 151 (1985) 369-374

[12] R.W. Congdon, G.W. Muth, A.G. Splittgerber, The binding interaction of Coomassie Blue with proteins, Anal. Biochem. 213 (1993) 407-413.

[13] J.J. Sedmak, S.E. Grossberg, A rapid, sensitive, and versatile assay for protein using Coomassie Brilliant Blue G250, Anal. Biochem. 79 (1977) 544-552.

[14] N. Kruger, The Protein Protocols Handbook, Part I: The Bradford Method for Protein Quantitation, second ed., Humana, Totowa, NJ, 2002.

[15] S. Friedenauer, H.H. Berlet, Sensitivity and variability of the Bradford protein assay in the presence of detergents, Anal. Biochem. 178 (1989) 263-268

[16] T. Marshall, K.M. Williams, Drug interference in the Bradford and 2,2'bicinchoninic acid protein assays, Anal. Biochem. 198 (1991) 352-354.

[17] S.P. Banik, S. Pal, S. Ghorai, S. Chowdhury, S. Khowala, Interference of sugars in the Coomassie Blue $\mathrm{G}$ dye binding assay of proteins, Anal. Biochem. 386 (2009) $113-115$.

[18] N. Carlsson, A. Borde, S. Wölfel, B. Åkerman, A. Larsson, Quantification of protein concentration by the Bradford method in the presence of pharmaceutical polymers, Anal. Biochem. 411 (2011) 116-121.

[19] H. Barbosa, N.K.H. Slater, J.C. Marcos, Protein quantification in the presence of poly(ethylene glycol) and dextran using the Bradford method, Anal. Biochem. 395 (2009) 108-110. 